\title{
Characteristics of $\mathrm{LaCo}_{1-\mathrm{x}} \mathrm{Ni}_{\mathrm{x}} \mathrm{O}_{3-\delta}$ Coated on $\mathrm{Ni} / \mathrm{YSZ}$ Anode using $\mathrm{CH}_{4}$ Fuel in Solid Oxide Fuel Cells
}

\author{
Jun Ho Kim, Geun Young Jang, Jeong Woo Yun* \\ ${ }^{1}$ School of Chemical Engineering, Chonnam National University, Gwangju 61186, Republic of Korea
}

\begin{abstract}
Nickel-doped lanthanum cobalt oxide $\left(\mathrm{LaCo}_{1-\mathrm{x}} \mathrm{Ni}_{\mathrm{x}} \mathrm{O}_{3-\delta}, \mathrm{LCN}\right)$ was investigated as an alternative anode material for solid oxide fuel cells. To improve its catalytic activity for steam methane reforming (SMR) reaction, $\mathrm{Ni}^{2+}$ was substituted into $\mathrm{Co}^{3+}$ lattice in $\mathrm{LaCoO}_{3}$. LCN anode, synthesized using the Pechini method, reacts with yttria-stabilized zirconia (YSZ) electrolyte at high temperatures to form an electrochemically inactive phase such as $\mathrm{La}_{2} \mathrm{Zr}_{2} \mathrm{O}_{7}$. To minimize the interlayer by-products, the LCN was coated via a double-tape casting method on the Ni/YSZ anode as a catalytic functional layer. By increasing the Ni doping amount, oxygen vacancies in the LCN increased and the cell performance improved. $\mathrm{CH}_{4}$ fuel decomposed to $\mathrm{H}_{2}$ and $\mathrm{CO}$ via SMR reaction in the LCN functional layer. Hence, the LCN-coated Ni/YSZ anode exhibited better cell performance than the Ni/YSZ anode under $\mathrm{H}_{2}$ and $\mathrm{CH}_{4}$ fuels. $\mathrm{LCN}$ with $12 \mathrm{~mol} \%$ of Ni (LCN12)-modified Ni/ YSZ anode showed excellent long-term stability under $\mathrm{H}_{2}$ and $\mathrm{CH}_{4}$ conditions.
\end{abstract}

Keywords : Solid Oxide Fuel Cell, Alternative Anode, $\mathrm{LaCo}_{1-\mathrm{x}} \mathrm{Ni}_{\mathrm{x}} \mathrm{O}_{3-\delta}$, Interlayer by-Product, Methane Fuel

Received : 6 March 2020, Accepted : 6 May 2020

\section{Introduction}

Solid oxide fuel cells (SOFCs) have received much attention as promising electrochemical conversion devices due to their high efficiency and environmental friendliness $[1,2]$. Due to their high temperature $\left(700-900^{\circ} \mathrm{C}\right.$ ) operation, SOFCs can use various types of fuels including natural gas, biogas, liquid hydrocarbons, and pure $\mathrm{H}_{2}$. Fuel flexibility can lower system operating costs and improve overall efficiency by eliminating additional reformers and/or purifiers $[3,4]$. The hydrocarbon fuels, however, can degrade catalytic properties in anode, especially by carbon coking and sulfur poisoning, leading to degradation of cell performance. Nickel and yttria-stabilized zirconia (Ni/YSZ) cermet is one of the most typical anode materials in SOFCs because of its excellent catalytic activity for fuel oxidation and good electrical conductivity. The Ni/YSZ anode, however, permits only a few hundred parts per million levels of

*E-mail address: jwyun@jnu.ac.kr

DOI: https://doi.org/10.33961/jecst.2020.00843

This is an open-access article distributed under the terms of the Creative Commons Attribution Non-Commercial License (http://creativecommons.org/licenses/by-nc/4.0) Attribution Non-Commercial License (http://creativecommons.org/licenses/by-nc/4.0)
which permits unrestricted non-commercial use, distribution, and reproduction in any which permits unrestricted non-commercial use, distrib
medium, provided the original work is properly cited. sulfur compounds contained in commercial hydrocarbon fuels. In addition, $\mathrm{Ni}$ phase of the $\mathrm{Ni} / \mathrm{YSZ}$ anode is easily deactivated by carbon deposition in hydrocarbon fuels resulting in severe degradation of cell performance [5-9].

To overcome the shortcomings of the Ni/YSZ cermet, many research groups have been developing alternative anodes for direct and practical utilization of hydrocarbon fuels [10-12]. However, alternative anodes of SOFCs must meet strict requirements such as good electrocatalytic activation, good electrical conductivity under reducing condition, chemical compatibility with electrolyte, and satisfied tolerance to carbon deposition and sulfur poisoning. Metalbased anodes including $\mathrm{Cu}, \mathrm{Co}, \mathrm{W}$, etc., are not appropriate to utilize commercial hydrocarbon fuels, although they have exhibited excellent performance as alternative anodes. Noble metals including $\mathrm{Ru}, \mathrm{Pd}$, and $\mathrm{Au}$ are beyond consideration due to their high cost. Modification of the Ni/YSZ anode by mixed ionic and electronic conductive (MIEC) materials can be one approach to inhibit carbon deposition. A porous thin film of samarium-doped ceria (SDC) on the Ni/YSZ anode improves the cell performance and minimizes carbon deposition $[13,14]$. Due to MIEC 
properties exhibited by SDC, carbon deposited on the SDC coating layer of the $\mathrm{Ni} / \mathrm{YSZ}$ anode reacts with $\mathrm{O}^{2-}$ ions to form $\mathrm{CO}$ or $\mathrm{CO}_{2}$ via electrochemical oxidation given by

$$
\mathrm{C}_{\text {surface }}+\mathrm{O}_{S D C}^{2-} \rightarrow \mathrm{CO} \text { or } \mathrm{CO}_{2}
$$

Doped perovskites $\left(\mathrm{AA}^{\prime} \mathrm{BB}^{\prime} \mathrm{O}_{3}\right)$ may be appropriate candidates as alternative anode materials [15-20]. In our previous research, electrochemical properties of alternative anode materials including $\mathrm{Sr}_{0.92} \mathrm{Y}_{0.08} \mathrm{TiO}_{3-\delta}$ [21], $\mathrm{Sr}_{0.92} \mathrm{Y}_{0.08} \mathrm{Ti}_{1-\mathrm{x}} \mathrm{Fe}_{\mathrm{x}} \mathrm{O}_{3-\delta}$ [22], $\mathrm{Sr}_{0.92} \mathrm{Y}_{0.08} \mathrm{Ti}_{1-\mathrm{x}}$ $\mathrm{Ni}_{\mathrm{x}} \mathrm{O}_{3-\delta}$ [23], and $\mathrm{Sr}_{2} \mathrm{NiMoO}_{6}$ [24] were investigated under $\mathrm{H}_{2}$ and $\mathrm{CH}_{4}$ fuels. Due to good stability under high temperatures, perovskite with $\mathrm{ABO}_{3}$ formula allows the substitution of alkaline, alkaline-earth, or lanthanide metals into A-sites and transition cations into B-sites such as Mn, Co, Fe, and Ti [25]. Multivalent state exhibiting transition metal cations as a function of oxygen partial pressure may provide electronic conductivity to the anode. Mis-valenced cations doped into B-sites can provide oxygen vacancies, leading to improved ionic conductivity. In addition, MIEC perovskites provide excellent compatibility with electrolyte and mechanical stability without thermal mismatch and/or structural failure during long-term operation. Because D. B. Meadowcroft group reports the use of lanthanum-based perovskite oxide as a catalyst, lanthanum-based perovskites have attracted increasing attention as bifunctional catalysts for oxygen reduction reaction (ORR) and oxygen evolution reaction (OER) [26]. Cobalt-based perovskites are one of the promising candidates for ORR activity. $\mathrm{LaCoO}_{3}$ exhibits better electrocatalytic activity compared to other perovskite oxides [27]. Yoon et al. improved cell performance and maintained cell stability for $200 \mathrm{~h}$ by coating the $\mathrm{LaNi}_{0.6} \mathrm{Co}_{0.4} \mathrm{O}_{3-\delta}$ catalyst layer on the $\mathrm{NiO}-\mathrm{BaZr}_{0.1} \mathrm{Ce}_{0.7} \mathrm{Y}_{0.1} \mathrm{Yb}_{0.1} \mathrm{O}_{3-\delta}(\mathrm{NiO}-\mathrm{BZCYYb})$ anode support through electron beam vapor deposition [28]. Zhang et al. reported that $\mathrm{La}_{0.6} \mathrm{Sr}_{0.4} \mathrm{Co}_{0.2} \mathrm{Fe}_{0.8} \mathrm{O}_{3-\delta}$ nanoparticles modified on Ni-based anode exhibited excellent coking resistance and improved cell performance [29]. In this study, electrochemical characteristics of $\mathrm{Ni} / \mathrm{YSZ}$ anode under methane fuel were studied by coating $\mathrm{LaCo}_{1-\mathrm{x}} \mathrm{Ni}_{\mathrm{x}} \mathrm{O}_{3-\delta}(\mathrm{LCN})$. To improve oxygen ion conductivity and ORR catalytic activity in the anode, $\mathrm{Ni}^{2+}$ was substituted into $\mathrm{Co}^{3+}$ of $\mathrm{LaCoO}_{3}$.

\section{Experimental}

\subsection{Cell preparation}

LCN was synthesized by the Pechini method in which the amount of nickel was changed to $1,4,7$, and $12 \mathrm{~mol} \%$. Lanthanum (III) nitrate hydrate $\left(\mathrm{La}\left(\mathrm{NO}_{3}\right)_{3} \cdot \mathrm{H}_{2} \mathrm{O}, 99.9 \%\right.$ trace metal, Sigma Aldrich) was mixed with $200 \mathrm{ml}$ of distilled water, citric acid anhydrous $\left(\mathrm{C}_{6} \mathrm{H}_{8} \mathrm{O}_{7}\right.$, Daejung), and ethylene glycol $\left(\mathrm{HOCH}_{2} \mathrm{CH}_{2} \mathrm{OH}\right.$, Sigma Aldrich) to dissolve La as the A-site material. Cobalt (II) nitrate hexahydrate $\left(\mathrm{Co}\left(\mathrm{NO}_{3}\right)_{2} \cdot 6 \mathrm{H}_{2} \mathrm{O}, \mathrm{ACS}\right.$ reagent, Sigma Aldrich) and nickel (II) nitrate hexahydrate $\left(\mathrm{Ni}\left(\mathrm{NO}_{3}\right)_{2} \cdot 6 \mathrm{H}_{2} \mathrm{O}\right.$, purum p.a., crystallized, Sigma Aldrich)) were dissolved in $200 \mathrm{ml}$ of ethanol $\left(\mathrm{CH}_{3} \mathrm{CH}_{2} \mathrm{OH}\right.$, Sigma Aldrich) to dissolve $\mathrm{Co}$ and $\mathrm{Ni}$ as $\mathrm{B}$-site materials. The solution was adjusted to $\mathrm{pH}$ 6-7 by adding ammonium hydroxide solution (Sigma Aldrich). After solubilizing with some additives, the solution was dried at $120^{\circ} \mathrm{C}$ and calcined at $350^{\circ} \mathrm{C}$. Subsequently, the calcined sample was heated to $650^{\circ} \mathrm{C}$ at the rate of $1^{\circ} \mathrm{C} / \mathrm{min}$ to form a perovskite structure. The synthesized crystal structure was analyzed by an X-ray diffractometer (XRD, Rigaku, RINT-5200). The formation of the LCN phase was analyzed using TGA/DTA (STA PT1600, TA, USA). The microstructure was analyzed using a scanning electron microscope (FE-SEM, Hitachi, S-4200, Japan). To investigate the electrochemical and electrocatalytic performances, button-type electrolyte substrates were prepared using $8 \mathrm{~mol} \%$ of yttria-stabilized zirconia (8YSZ, Fuel cell materials) powder by uniaxial dry pressing and sintered at $1400^{\circ} \mathrm{C}$ for $5 \mathrm{~h}$. The $8 \mathrm{YSZ}$ electrolyte substrate was 0.9 and $25.2 \mathrm{~mm}$ in thickness and diameter, respectively. For the anode, Ni/ YSZ slurry was tape-casted on the YSZ electrolyte and subsequently sintered at $1400^{\circ} \mathrm{C}$ for $5 \mathrm{~h}$. The LCN slurry was tape-casted on the Ni/YSZ electrode layer to form a catalytic functional layer and subsequently sintered at $1200^{\circ} \mathrm{C}$ for $10 \mathrm{~h}$. The thicknesses of the Ni/YSZ electrode layer and the LCN catalytic layer were about 35 and $25 \mu \mathrm{m}$, respectively. For the cathode, $\mathrm{La}_{0.8} \mathrm{Sr}_{0.2} \mathrm{MnO}_{3}$ (LSM, Fuel cell materials) was tape-casted on the YSZ electrolyte and subsequently sintered at $1100^{\circ} \mathrm{C}$ for $10 \mathrm{~h}$.

\subsection{Cell characteristics}

To investigate the electrochemical performance, a disk-type cell was mounted between double-layered 


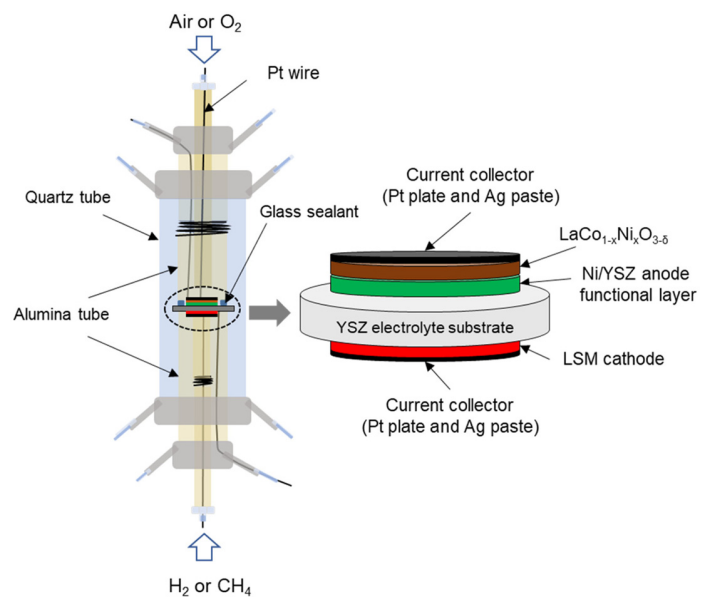

Fig. 1. Schematic representation of the experimental setup for cell housing in the reactor.

alumina tubes and sealed with Pyrex glass on the dense electrolyte, as shown in Fig. 1. A perforated $\mathrm{Pt}$ plate $\left(1 \mathrm{~cm}^{2}\right.$ in area) and $\mathrm{Ag}$ paste were used as current collectors. For the anode, humidified hydrogen $\left(\sim 5\right.$ vol. $\left.\% \mathrm{H}_{2} \mathrm{O}\right)$ and humidified methane $\left(\sim 5\right.$ vol. $\left.\% \mathrm{H}_{2} \mathrm{O}\right)$ were used as fuel gases and supplied at a flow rate of $200 \mathrm{~mL} / \mathrm{min}$. For the cathode, $\mathrm{O}_{2}$ was supplied at a rate of $200 \mathrm{~mL} / \mathrm{min}$ as an oxidant gas. The electrochemical characteristics were analyzed using an impedance analysis device (SP-150, Biologic Science Instrument). The impedance spectra were recorded in the frequency range from $10^{-2}-10^{6}$ $\mathrm{Hz}$ at an excited voltage of $10 \mathrm{mV}$ to ensure linear response. The impedance analyses were performed between 750 and $850^{\circ} \mathrm{C}$, where the Nyquist plot indicated an equilibrium state.

\section{Results and Discussion}

\subsection{Physical properties}

Fig. 2 shows the TGA/DTA results for the LCN resin obtained at the rate of $10^{\circ} \mathrm{C} / \mathrm{min}$ in air. The analytical results show four areas related to precursor decomposition for all samples due to removal of volatile compounds and decomposition of nitrate and citric acid as described by Lee et al. [30]. The first region below $200^{\circ} \mathrm{C}$ is due to the evaporation of weakly adsorbed water and volatiles. The rapid weight-degrading region between 200 and $400^{\circ} \mathrm{C}$ corresponds to the decomposition of nitrates and citrates. The region in the range of $400-650^{\circ} \mathrm{C}$ is due

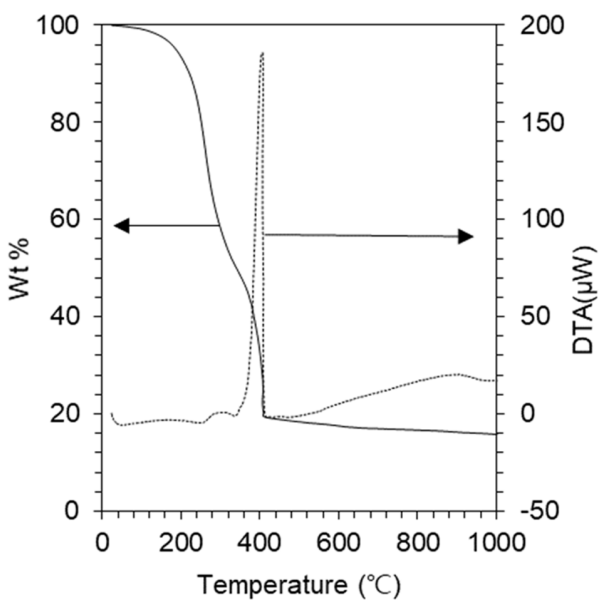

Fig. 2. TGA and DTA curves of the precursor resin synthesized by the Pechini method using air at a flow rate of $10^{\circ} \mathrm{C} / \mathrm{min}$.

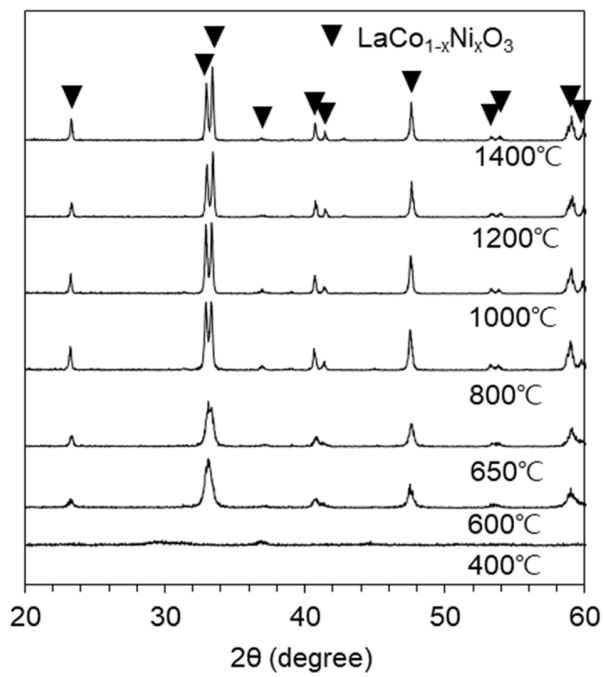

Fig. 3. X-ray diffraction (XRD) patterns of $\mathrm{LaCo}_{1-\mathrm{x}} \mathrm{Ni}_{\mathrm{x}} \mathrm{O}_{3}$ calined at varying temperatures in air.

to the decomposition of nitrite and carbonate [31]. The small exothermic peak observed between 450 and $500^{\circ} \mathrm{C}$ in the DTA curves may be attributed to the crystallization of the LCN perovskite phase. The results correspond to the XRD data as shown in Fig. 3. The crystal structure of the synthesized perovskite oxide, LCN, was characterized by XRD at varying temperatures $(400,600,650,800,1000,1200$, and $1400^{\circ} \mathrm{C}$ ) in air. No noticeable peaks were detected for the sample calcined at $400^{\circ} \mathrm{C}$, in which the perovskite 

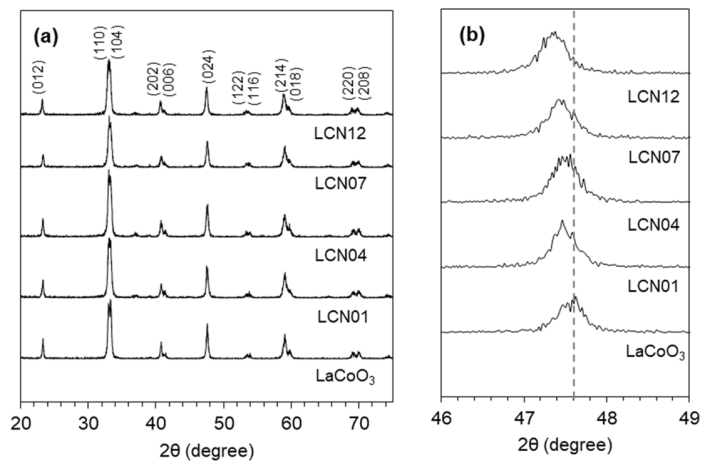

Fig. 4. $\mathrm{XRD}$ patterns of (a) $\mathrm{LaCo}_{1-\mathrm{x}} \mathrm{Ni}_{\mathrm{x}} \mathrm{O}_{3}(\mathrm{x}=0,0.01$, $0.04,0.07$, and 0.12 ) with varying amounts of nickel: $0 \mathrm{~mol} \%\left(\mathrm{LaCoO}_{3}\right), 1 \mathrm{~mol} \%$ (LCN01), $4 \mathrm{~mol} \%$ (LCN04), $7 \mathrm{~mol} \%$ (LCN07), and $12 \mathrm{~mol} \%$ (LCN12) and (b) peak shifts with varying amounts of nickel.

crystalline structure was not formed. The perovskite structure of LCN was observed at $600^{\circ} \mathrm{C}$ and was prominent at $650^{\circ} \mathrm{C}$. Up to $1400^{\circ} \mathrm{C}$, no extra peaks emerged from any of the perovskite oxides, suggesting that there were no impurities and the perovskite phase is stable at high temperatures.

Fig. 4(a) shows the XRD patterns of the LCN sample with the degree of $\mathrm{Ni}$ substitution. The substitution amount of $\mathrm{Ni}$ as the B-site dopant was varied between $0 \mathrm{~mol} \%$ (LCO), $1 \mathrm{~mol} \%$ (LCN01), $4 \mathrm{~mol} \%$ (LCN04), $7 \mathrm{~mol} \%$ (LCN07), and $12 \mathrm{~mol} \%$ (LCN12). No additional peaks were detected in LCO, LCN01, LCN04, LCN07, and LCN12 except in the lanthanum cobalt-based perovskite structure. It was observed that all peaks shifted slightly toward low angles with increase in nickel substitution amount as shown in Fig. 4(b). Replacement of Co with Ni led to lattice expansion due to the larger ionic radius of $\mathrm{Ni}^{2+}$ (0.69 $\AA$ for six coordination) as compared to that of $\mathrm{Co}^{3+}(0.61 \AA$ for six coordination), resulting in the peak to shift to low angles. Over $12 \mathrm{~mol} \%$ of Ni dopant, the LCN phase was unstable and $\mathrm{NiO}$ and $\mathrm{Ni}$ phase were detected. Due to the excellent catalytic performance shown in Ni phase, the cell performance can be improved in increasing Ni dopant amounts in the LCN. However, the chemical stability of LCN phase decreases in increasing $\mathrm{Ni}$ dopant amounts and $\mathrm{NiO}$ and/or Ni phase can be exsoluted [32]. The NiO and $\mathrm{Ni}$ phase can serve as a major source of carbon deposition and significantly degrades cell performance.

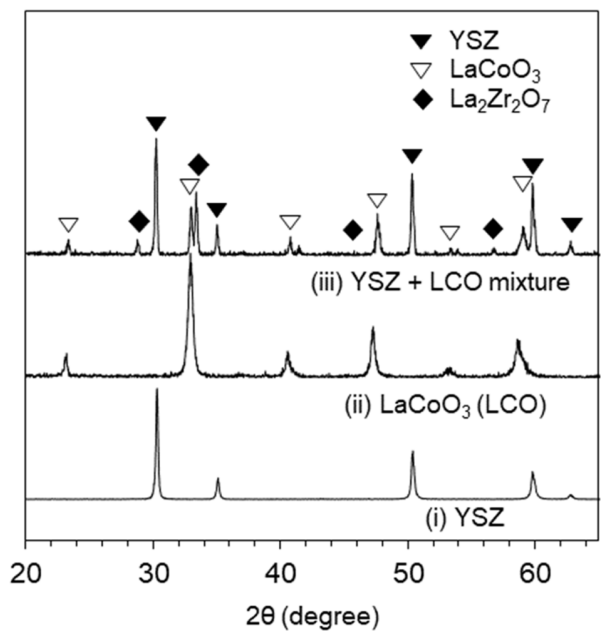

Fig. 5. Chemical compatibility analysis based on the XRD patterns of (i) YSZ, (ii) $\mathrm{LaCoO}_{3}$ (LCO), and YSZ/LCO mixture.

\subsection{Chemical compatibility with YSZ electrolyte}

Fig. 5 presents the XRD patterns of (i) YSZ, (ii) LCO, and (iii) YSZ-LCO mixture to investigate chemical compatibility between the LCO anode and YSZ electrolyte. LCO and YSZ powders were mixed in a 1:1 weight ratio by dry ball milling for $24 \mathrm{~h}$. The $\mathrm{LCO} / \mathrm{YSZ}$ mixture powder was co-sintered at $1200^{\circ} \mathrm{C}$ for $10 \mathrm{~h}$, which is the temperature at which the anode can maintain sufficient adhesion to the electrolyte. In the case of the YSZ-LCO mixture, La reacted with $\mathrm{Zr}$ to form $\mathrm{La}_{2} \mathrm{Zr}_{2} \mathrm{O}_{7}$, which is an electronic and ionic resistant material. The XRD results correspond to the SEM image as shown in Fig. 6. During sintering at high temperature, the interfacial reaction product, $\mathrm{La}_{2} \mathrm{Zr}_{2} \mathrm{O}_{7}$, of 1-2 $\mu \mathrm{m}$ thickness, was formed between the LCO anode and YSZ electrolyte. Therefore, to minimize the unfavorable by-product formation, Ni/YSZ with 70 vol.\% of $\mathrm{Ni}$ as an anode functional layer was located between the YSZ electrolyte and LCN layer as shown in Fig. 7. The LCN layer minimized the direct exposure of $\mathrm{CH}_{4}$ to the $\mathrm{Ni} / \mathrm{YSZ}$ anode, where carbon deposition could occur under $\mathrm{CH}_{4}$ fuel. Due to the very high catalytic activity exhibited in the $\mathrm{Ni}$ / YSZ phase, hydrocarbon fuels including $\mathrm{CH}_{4}$ would decompose rapidly to $\mathrm{C}$ and $\mathrm{H}_{2}$ via pyrolysis, resulting in carbon deposition on the Ni/YSZ anode. However, the LCN layer tape-casted on the Ni/YSZ anode acted as a catalytic functional layer. $\mathrm{H}_{2} \mathrm{O}$ from 


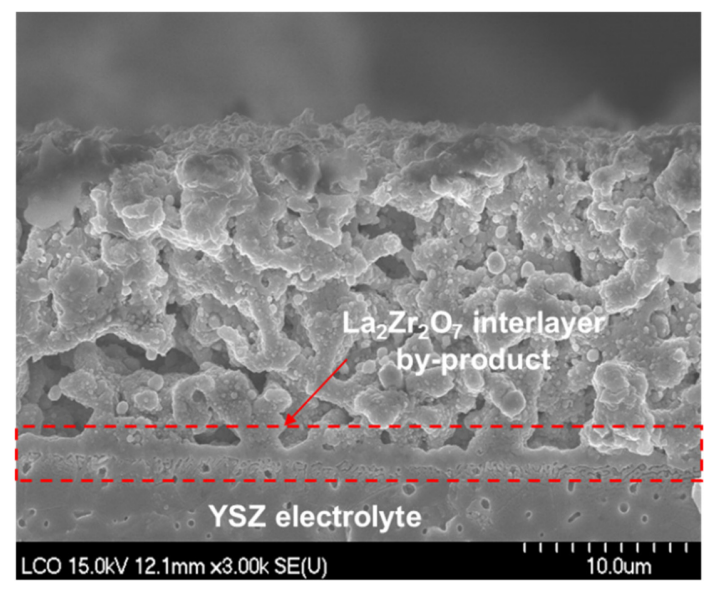

Fig. 6. SEM image of cut-view between the YSZ electrolyte and $\mathrm{LCN}$ anode.

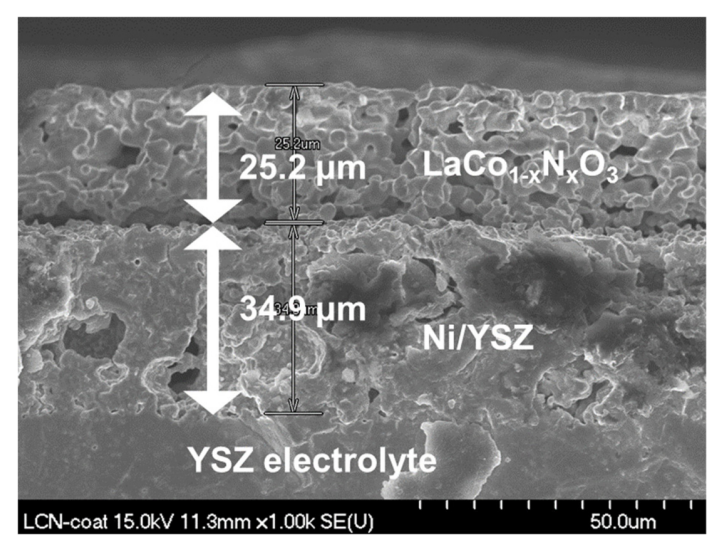

Fig. 7. SEM image of cut-view of the LCN-modified Ni/ YSZ anode layer.

the humidified $\mathrm{CH}_{4}$ and from the emitted gas via electrochemical oxidation reacted with $\mathrm{CH}_{4}$ via steam methane reforming (SMR) on the LCN catalytic layer as follows:

$$
\begin{aligned}
& \mathrm{CH}_{4}+\mathrm{H}_{2} \mathrm{O} \rightarrow \mathrm{CO}+3 \mathrm{H}_{2} \\
& \mathrm{CO}+\mathrm{H}_{2} \mathrm{O} \rightarrow \mathrm{CO}_{2}+\mathrm{H}_{2} \\
& \mathrm{H}_{2}+\mathrm{O}^{2-} \rightarrow \mathrm{H}_{2} \mathrm{O}+2 \mathrm{e} \\
& \mathrm{CO}+\mathrm{O}^{2-} \rightarrow \mathrm{CO}_{2}+2 \mathrm{e} \\
& \mathrm{CH}_{4}+\mathrm{O}^{2-} \rightarrow \mathrm{CO}+2 \mathrm{H}_{2}+2 \mathrm{e}
\end{aligned}
$$

Therefore, most of the $\mathrm{CH}_{4}$ decomposed to $\mathrm{H}_{2}$ and $\mathrm{CO} / \mathrm{CO}_{2}$ via SMR (reaction (2)) and water gas shift (WGS) reactions (reaction (3)) in the LCN catalytic layer. The produced $\mathrm{H}_{2}$ and $\mathrm{CO}$ reacted with $\mathrm{O}^{2-}$ to produce $\mathrm{H}_{2} \mathrm{O}$ and $\mathrm{CO}_{2}$ electrochemically via reaction (4) and (5) in the Ni/YSZ layer. In addition, the undecomposed $\mathrm{CH}_{4}$ reacted with $\mathrm{O}^{2-}$ via electrochemical oxidation (reaction (6)) in triple phase boundary (TPB) of the $\mathrm{Ni} / \mathrm{YSZ}$ anode. Although $\mathrm{La}_{2} \mathrm{Zr}_{2} \mathrm{O}_{7}$ was formed in the interlayer between the $\mathrm{LCN}$ and $\mathrm{Ni} /$ YSZ layers, $70 \mathrm{vol} \% \%$ of $\mathrm{Ni}$ and $50 \mathrm{vol} \%$ of porosity in the Ni/YSZ anode minimized the $\mathrm{La}_{2} \mathrm{Zr}_{2} \mathrm{O}_{7}$ formation. In addition, small amounts of $\mathrm{La}_{2} \mathrm{Zr}_{2} \mathrm{O}_{7}$ in the $\mathrm{LCN}$ and $\mathrm{Ni} / \mathrm{YSZ}$ interlayer were negligible to the catalytic performance for SMR because most electrochemical reactions, which are critically affected by $\mathrm{La}_{2} \mathrm{Zr}_{2} \mathrm{O}_{7}$, occur in the $\mathrm{Ni} / \mathrm{YSZ}$ anode functional layer, especially near the YSZ electrolyte.

\subsection{EIS analysis}

Fig. 8 shows the electrochemical impedance spectroscopy (EIS) results of Ni/YSZ and LCNmodified Ni/YSZ with the YSZ electrolyte and LSM cathode with varying $\mathrm{Ni}$ amounts in (a) $\mathrm{H}_{2}(\sim 5$ vol.\% of $\left.\mathrm{H}_{2} \mathrm{O}\right)$ and (b) $\mathrm{CH}_{4}\left(\sim 5\right.$ vol.\% of $\left.\mathrm{H}_{2} \mathrm{O}\right)$ at $800^{\circ} \mathrm{C} . \mathrm{H}_{2}$ and $\mathrm{CH}_{4}$ were humidified in a bubbler before being inserted into the reactor at the rate of $200 \mathrm{ml} / \mathrm{min}$ and pure $\mathrm{O}_{2}$ was used as an oxidant gas at the same rate. EIS results were obtained under open circuit voltage (OCV) conditions. Nyquist plots of $Z_{\text {real }}\left(\operatorname{Re} Z^{\prime}\right)$ vs. $Z_{\text {imaginary }}\left(\operatorname{Im} Z^{\prime \prime}\right)$ as a function of frequency ( 0.01 to $10^{6} \mathrm{~Hz}$ ) under $10 \mathrm{mV}$ current conditions were drawn to ensure linear response. Because analysis of the impedance spectra of a multi-layered fuel cell is very complicated and mostly uncertain, we discuss and explain the overall polarization resistance of the sample. The effects of impedance spectra can be attributed to the anode because the cathode and the electrolyte are the same in all the samples. In our experimental, the SMR can be limited because of low amounts of $\mathrm{H}_{2} \mathrm{O}(\sim 5 \mathrm{wt} \%)$. Therefore, the electrochemical oxidation of $\mathrm{H}_{2}$ via the reaction (4) will compete to $\mathrm{CH}_{4}$ oxidation via the reaction (6), which also occurs $\mathrm{CH}_{4}$ pyrolysis. Because of the slower reaction of $\mathrm{CH}_{4}$ electrochemical oxidation than $\mathrm{H}_{2}$ electrochemical oxidation and carbon deposition by $\mathrm{CH}_{4}$ pyrolysis, the overall polarization resistance increased in $\mathrm{CH}_{4}$ fuel condition. Under $\mathrm{H}_{2}$ conditions, the polarization resistances of the bare, 
LCN01-modified, LCN04-modified, and LCN12modified Ni/YSZ anodes were 4.52, 3.88, 0.88, and $0.56 \Omega \mathrm{cm}^{2}$, respectively. The polarization resistances decreased with increasing amounts of $\mathrm{Ni}$ substitution in the $\mathrm{LCN}$. Under $\mathrm{CH}_{4}$ conditions, the polarization resistances of the bare, LCN01-modified, LCN04modified, and LCN12-modified Ni/YSZ anodes were $54.3,38.7,31.2$, and $6.9 \Omega \mathrm{cm}^{2}$, respectively. Lower reaction kinetics and slower gas diffusion were exhibited under $\mathrm{CH}_{4}$ conditions than those under $\mathrm{H}_{2}$, thereby increasing the polarization resistance under $\mathrm{CH}_{4}$. The polarization resistance of the bare Ni/YSZ anode was significantly increased compared to that of the LCN12-modified Ni/YSZ anode under $\mathrm{CH}_{4}$ conditions. $\mathrm{CH}_{4}$ decomposed to $\mathrm{C}$ and $\mathrm{H}_{2}$ via pyrolysis of methane in the Ni phase of the Ni/YSZ anode leading to carbon deposition. The deposited carbon deactivated the TPB area and increased the mass transport resistance in the anode, resulting in the increase of low frequency arc $(>1 \mathrm{~Hz})$ in the impedance spectra. However, in the LCN12modified Ni/YSZ anode, $\mathrm{CH}_{4}$ decomposed to $\mathrm{H}_{2}$ and
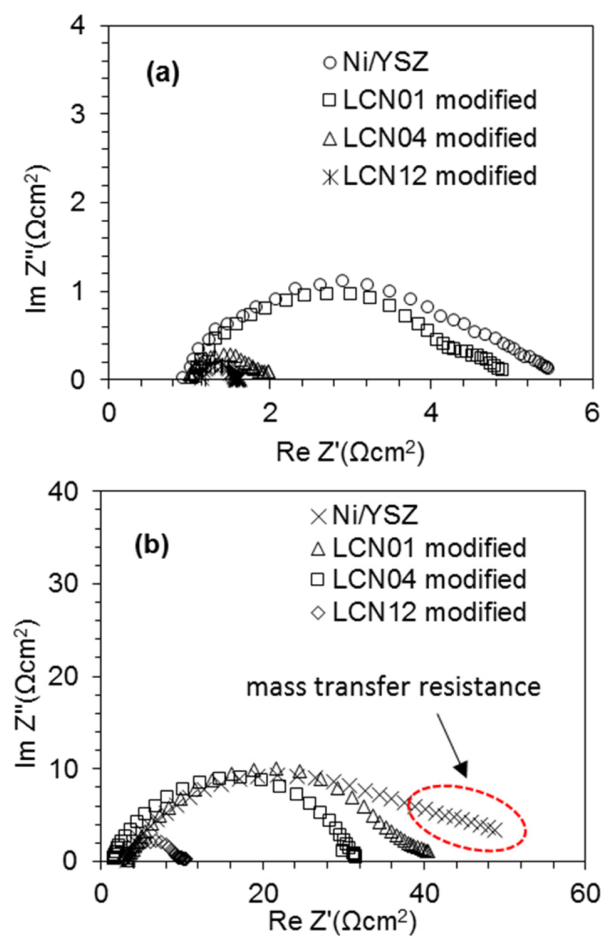

Fig. 8. Impedance spectra of bare, LCN01-modified, LCN04-modified, and LCN12-modified Ni/YSZ anodes at $800^{\circ} \mathrm{C}$ in (a) $\mathrm{H}_{2}$ and (b) $\mathrm{CH}_{4}$.
CO via SMR in the LCN12 layer, and subsequently, the decomposed $\mathrm{H}_{2}$ and $\mathrm{CO}$ reacted with $\mathrm{O}^{2-}$ electrochemically in the $\mathrm{Ni} / \mathrm{YSZ}$ layer. $\mathrm{H}_{2} \mathrm{O}$ for the SMR was obtained from humidified $\mathrm{CH}_{4}$ and the electrochemical reaction of $\mathrm{H}_{2}$ in the $\mathrm{Ni} / \mathrm{YSZ}$ anode. In addition, $\mathrm{CH}_{4}$ reacted with $\mathrm{CO}_{2}$ from the electrochemical reaction of $\mathrm{CO}$ in the $\mathrm{Ni} / \mathrm{YSZ}$ anode and WGS reaction via reaction (3). The existence of dry methane reforming $\left(\mathrm{CH}_{4}+\mathrm{CO}_{2} \rightarrow 2 \mathrm{CO}+2 \mathrm{H}_{2}\right)$ in the LCN12-modified Ni/YSZ anode will contribute to our further research.

\subsection{I-V characteristics}

Fig. 9 shows the I-V characteristics of the electrolyte supported single cell with the bare and LCN-modified Ni/YSZ anodes in (a) $\mathrm{H}_{2}$ and (b) $\mathrm{CH}_{4}$
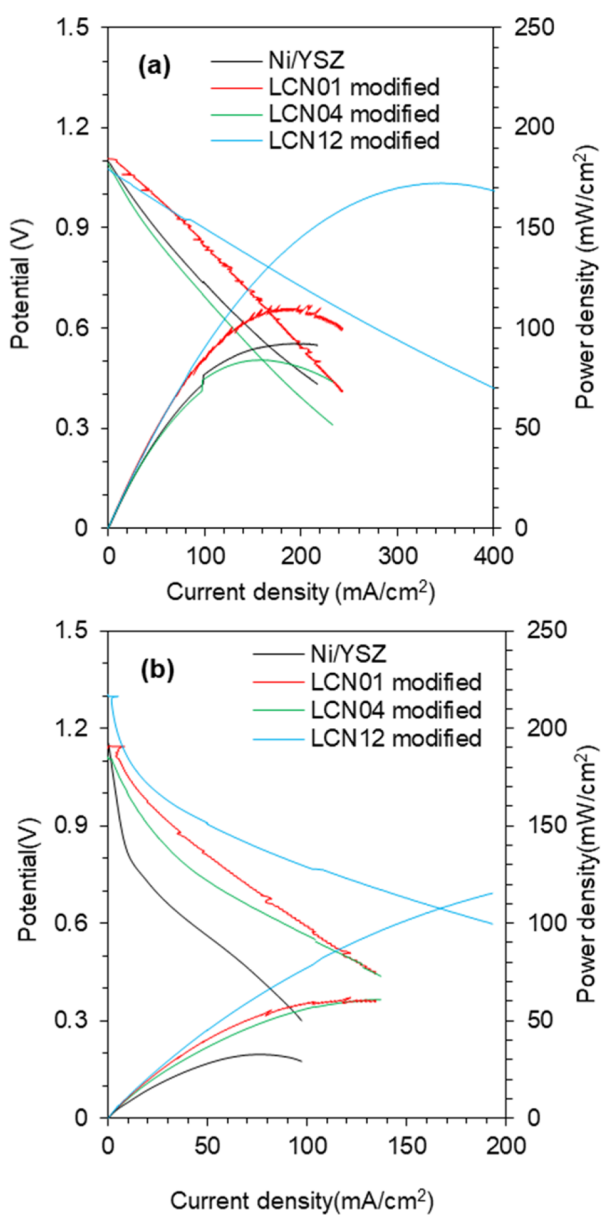

Fig. 9. I-V characteristics of a single cell with bare, LCN01-modified, LCN04-modified, and LCN12-modified $\mathrm{Ni} / \mathrm{YSZ}$ anodes at $800^{\circ} \mathrm{C}$ in (a) $\mathrm{H}_{2}$ and (b) $\mathrm{CH}_{4}$. 
at $800^{\circ} \mathrm{C}$. After stabilizing the cell in $\mathrm{H}_{2}$ or $\mathrm{CH}_{4}$ at $800^{\circ} \mathrm{C}$, the $\mathrm{I}-\mathrm{V}$ characteristics were measured with $200 \mathrm{~mL} / \mathrm{min}$ of humidified $\mathrm{H}_{2}\left(5 \mathrm{vol} . \%\right.$ of $\left.\mathrm{H}_{2} \mathrm{O}\right)$ or humidified $\mathrm{CH}_{4}\left(5 \mathrm{vol} \%\right.$ of $\left.\mathrm{H}_{2} \mathrm{O}\right)$ as the anode fuel and $\mathrm{O}_{2}$ as the cathode gas. The $\mathrm{OCV}$ was $1.1 \mathrm{~V}$ in $\mathrm{H}_{2}$ and increased to $1.15 \sim 1.3 \mathrm{~V}$ in $\mathrm{CH}_{4}$ due to the increasing chemical potential $(\Delta \mathrm{G})$ of methane oxidation, which reported in our previous research [33]. Even though many possible mechanisms could be coupled to determine the $\mathrm{OCV}$, the governing mechanism under the high ratio of $\mathrm{CH}_{4} / \mathrm{H}_{2} \mathrm{O}$ conditions likely involved the electrochemical oxidation of methane via reactions (6). The maximum power density of the bare, LCN01-modified, LCN04-modified, and LCN12-modified Ni/YSZ anodes were 92.3, 111.1, 84.1 , and $172.6 \mathrm{~mW} / \mathrm{cm}^{2}$, respectively, under $\mathrm{H}_{2}$ conditions. Owing to the extended surface area by the LCN modification on the Ni/YSZ anode, the cell performance tended to improve in the LCN-modified $\mathrm{Ni} / \mathrm{YSZ}$ anode. For the LCN12-modified Ni/YSZ anode, the cell performance significantly improved compared to the LCN01 and LCN04-modified Ni/YSZ anodes. The aliovalent substitution of $\mathrm{Ni}^{2+}$ into $\mathrm{Co}^{3+}$ increased the oxygen vacancies in the LCN phase resulting in improved ionic conductivity given by
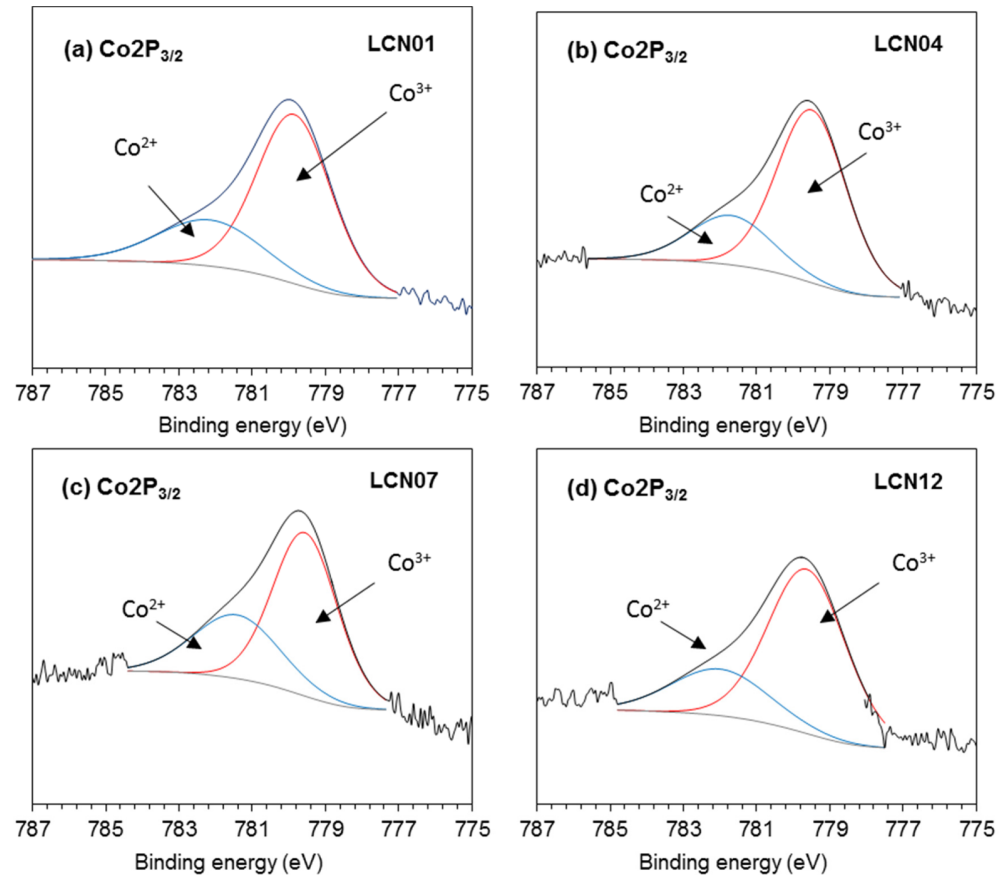

Fig. 10. XPS spectra of Co 2 $p_{3 / 2}$ and representative fitting for (a) LCN01, (b) LCN04, (c) LCN07, and (d) LCN12.
This aliovalent substitution via reaction (7) forms lattice defects to maintain electrical neutrality of the crystals. $\mathrm{Co}^{3+}(0.61 \AA$ in ionic radii for six coordination) in the B-site of $\mathrm{LaCoO}_{3}$ was substituted by $\mathrm{Ni}^{2+}$ (0.69 $\AA$ in ionic radii for six coordination) resulting in the creation of oxygen vacancies with a pair of electron holes. In addition, the existence of the mixed valence states of $\mathrm{Ni}^{2+} / \mathrm{Ni}^{3+}$ and $\mathrm{Co}^{3+} / \mathrm{Co}^{4+}$ in the reducing atmospheric condition could affect to the improvement of electrical conductivity and cell performance. In $\mathrm{CH}_{4}$, the maximum power density decreased to $32.68 \mathrm{~mW} / \mathrm{cm}^{2}$ (65\% decrease) for the $\mathrm{Ni} / \mathrm{YSZ}$ anode and $125.56 \mathrm{~mW} / \mathrm{cm}^{2}$ (27\% decrease) for the LCN-modified Ni/YSZ anode. Due to the LCN catalytic functional layer, $\mathrm{CH}_{4}$ was decomposed to $\mathrm{H}_{2}$ and $\mathrm{CO}$. The decomposed gas reacted with oxygen ion electrochemically to produce $\mathrm{H}_{2} \mathrm{O}, \mathrm{CO}_{2}$, and electrons in the $\mathrm{Ni} / \mathrm{YSZ}$ electrode functional layer. The low intrinsic catalytic activity exhibited in the LCN phase reduced $\mathrm{CH}_{4}$ pyrolysis and minimized carbon deposition in the anode. Oxygen vacancies formed by $\mathrm{Ni}^{2+}$ substitution via reaction (7) improved the catalytic properties of $\mathrm{CH}_{4}$ oxidation. 

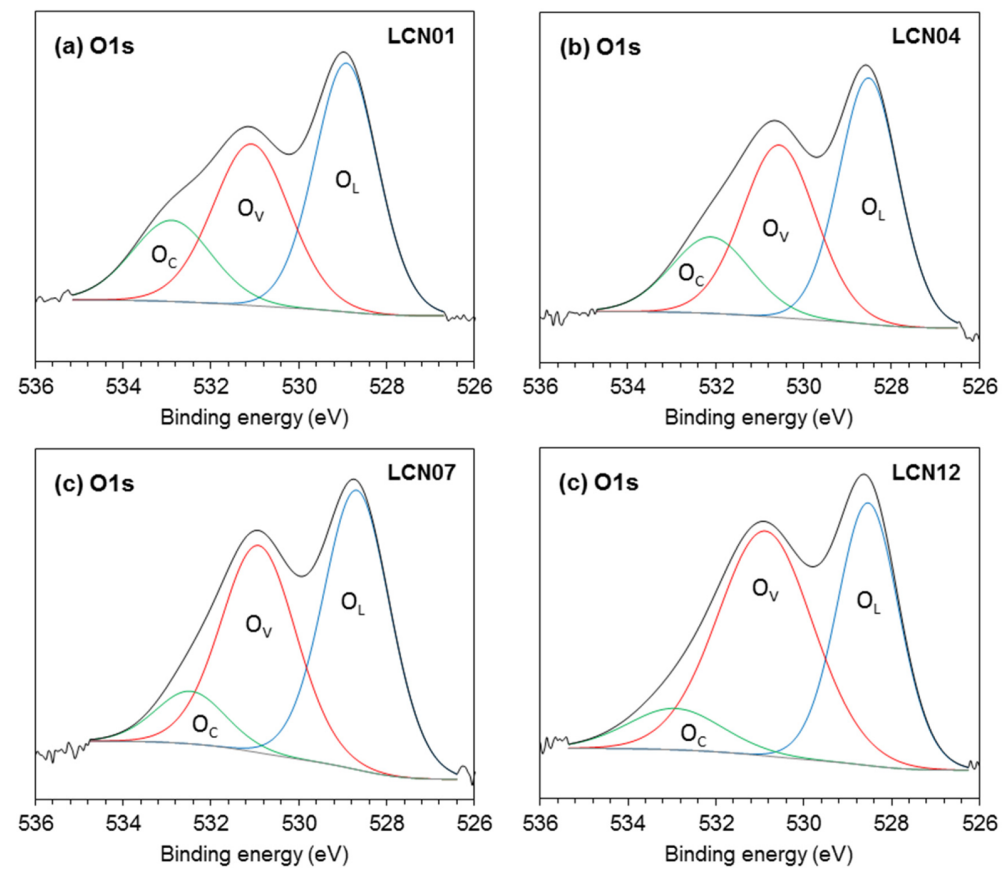

Fig. 11. XPS spectra of O 1s and representative fitting for (a) LCN01, (b) LCN04, (c) LCN07, and (d) LCN12.

\subsection{XPS analysis}

X-ray photoelectron spectroscopy (XPS) was used to investigate the chemical binding characteristics of the LCN surface element composition. Fig. 10 shows the XPS spectra in the Co $2 p_{3 / 2}$ regions. The peak located around $780 \mathrm{eV}$ corresponds to the binding energy of Co $2 p_{3 / 2}$. The peak can be deconvoluted into two peaks with binding energies of 779.6 and $781.8 \mathrm{eV}$, which are attributed to $\mathrm{Co}^{3+}$ and $\mathrm{Co}^{2+}$ ions, respectively. By increasing the amount of $\mathrm{Ni}^{2+}$ substitution, the $\mathrm{Co}^{3+} / \mathrm{Co}^{2+}$ ratio increased. New active sites of $\mathrm{Ni}^{2+} / \mathrm{Ni}^{3+}$ formed by Ni substitution were difficult to detect because $\mathrm{Ni} 2 \mathrm{p}$ peaks were overlapped by La $3 \mathrm{~d}$ peaks. Different surface oxygen states were identified by O 1s XPS spectra shown in Fig. 11. Three clear sub-peaks were observed in the samples. The largest sub-peak, observed around $528.6 \mathrm{eV}$ (blue peak in Fig. 11), is associated with lattice oxygen or highly oxidative oxygen species $\left(\mathrm{O}_{\mathrm{L}}\right)$. The sub-peak that was observed around $530.8 \mathrm{eV}$ (red peak in Fig. 11) represents the contribution of chemically adsorbed oxygen on the oxygen vacancies $\left(\mathrm{O}_{\mathrm{V}}\right)$. The smallest sub-peak, observed around $532.5 \mathrm{eV}$ (green peak in
Table 1. Summary of XPS peak deconvolution results of Co $2 p_{3 / 2}$ and $\mathrm{O} 1$ s from Fig. 10 and Fig. 11.

\begin{tabular}{cccccc}
\hline \hline \multirow{2}{*}{ Samples } & \multicolumn{2}{c}{$\mathrm{Co} 2 \mathrm{p}_{3 / 2}$} & \multicolumn{3}{c}{$\mathrm{O} 1 \mathrm{~s}$} \\
\cline { 2 - 6 } & $\mathrm{Co}^{3+}$ & $\mathrm{Co}^{2+}$ & $\mathrm{O}_{\mathrm{L}}$ & $\mathrm{O}_{\mathrm{V}}$ & $\mathrm{O}_{\mathrm{C}}$ \\
\hline LCN01 & $63.7 \%$ & $36.3 \%$ & $45.5 \%$ & $35.9 \%$ & $18.6 \%$ \\
LCN04 & $66.3 \%$ & $33.7 \%$ & $44.0 \%$ & $37.9 \%$ & $18.1 \%$ \\
LCN07 & $64.4 \%$ & $35.6 \%$ & $49.1 \%$ & $41.2 \%$ & $9.7 \%$ \\
LCN12 & $69.0 \%$ & $31.0 \%$ & $38.8 \%$ & $51.8 \%$ & $9.4 \%$ \\
\hline
\end{tabular}

Fig. 11), corresponds to physically adsorbed oxygen species $\left(\mathrm{O}_{\mathrm{C}}\right)$ on the surface such as $\mathrm{H}_{2} \mathrm{O}$. The relative amounts of the different states of cobalt and oxygen species, estimated from the relative area in the fitted peaks (Fig. 10 and 11), are listed in Table 1. The atomic ratio (\%) of the chemically adsorbed oxygen to the oxygen vacancies were $35.9,37.5$, 41.2 , and $51.8 \%$ in LCN01, LCN04, LCN07, and LCN12, respectively. This indicates that the oxygen vacancies were formed due to oxygen loss by $\mathrm{Ni}^{2+}$ substitution via reaction (7). 


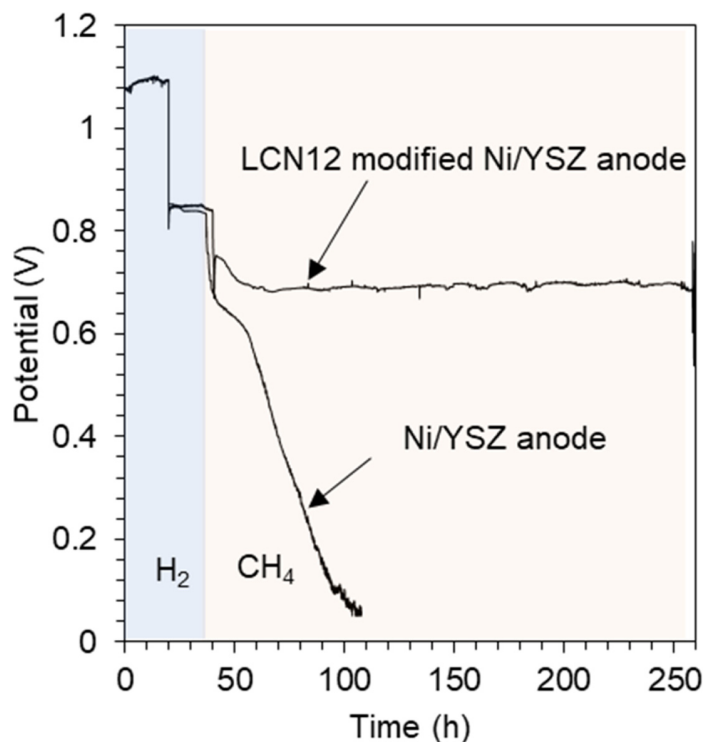

Fig. 12. Long-term test of a single cell with bare [22] and LCN12-modified Ni/YSZ anodes at $800^{\circ} \mathrm{C}$.

\subsection{Long-term stability}

To analyze the long-term stability of the LCN12modified Ni/YSZ anode, which exhibited the best performance in terms of the I-V characteristics, the performance of the $8 \mathrm{YSZ}$ electrolyte-supported single cell was measured under a constant current of $120 \mathrm{~mA} / \mathrm{cm}^{2}$ at $800^{\circ} \mathrm{C}$, as shown in Fig. 12. The performance was compared to that of the Ni/YSZ anode reported previously [22]. After $10 \mathrm{~h}$ of stabilizing the cell in humidified $\mathrm{H}_{2}$, humidified $\mathrm{CH}_{4}$ was introduced as the anode fuel. The cell performance of the LCN12-modified Ni/YSZ anode decreased in a few hours after introducing $\mathrm{CH}_{4}$ and subsequently stabilized at $0.685 \mathrm{~V}$. For the Ni/YSZ anode, the cell performance rapidly decreased in the presence of $\mathrm{CH}_{4}$ because of carbon deposition [21-24]. Otherwise,, the cell performance of the LCN-modified Ni/YSZ anode showed no significant degradation for $200 \mathrm{~h}$. The LCN12 catalytic functional layer minimized the direct exposure of $\mathrm{CH}_{4}$ to the Ni phase, where most of the carbon deposition occurred. Therefore, $\mathrm{CH}_{4}$ reacted with $\mathrm{H}_{2} \mathrm{O}$ from the bubbler and/or the electrochemical reaction in the $\mathrm{Ni} / \mathrm{YSZ}$ layer to form $\mathrm{H}_{2}$ and $\mathrm{CO}$ via $\mathrm{SMR}$ reaction. In addition, the oxygen vacancies by $\mathrm{Ni}^{2+}$ substitution via reaction (7) improved the catalytic activity for the SMR reaction.

\section{Conclusions}

LCN was modified on the Ni/YSZ anode as a catalytic functional layer to evaluate its feasibility as an alternative anode. To improve the catalytic activity for SMR reaction, $\mathrm{Ni}^{2+}$ was substituted into $\mathrm{Co}^{3+}$ lattice in $\mathrm{LaCoO}_{3}$. By increasing the Ni doping amount, oxygen vacancies in the LCN increased and the cell performance improved. $\mathrm{CH}_{4}$ fuel decomposed to $\mathrm{H}_{2}$ and $\mathrm{CO}$ via SMR reaction in the $\mathrm{LCN}$ functional layer. In addition, oxygen vacancies by Ni substitution improved the catalytic activity for the SMR reaction. The decomposed $\mathrm{H}_{2}$ and $\mathrm{CO}$ reacted with $\mathrm{O}^{2-}$ electrochemically in the Ni/YSZ layer. Consequently, the maximum power densities of the bare and LCN12-modified Ni/YSZ anodes under $\mathrm{H}_{2}$ conditions were 92.3 and $172.6 \mathrm{~mW} / \mathrm{cm}^{2}$, respectively. The maximum power densities under $\mathrm{CH}_{4}$ condition were $32.7 \mathrm{~mW} / \mathrm{cm}^{2}$ (65\% performance decrease) for the $\mathrm{Ni} / \mathrm{YSZ}$ anode and $125.6 \mathrm{~mW} / \mathrm{cm}^{2}$ (27\% performance decrease) for the LCN12-modified Ni/YSZ anode. The LCN12-modified Ni/YSZ anode showed excellent long-term stability under $\mathrm{H}_{2}$ and $\mathrm{CH}_{4}$ conditions. Otherwise, the cell performance of the LCNmodified Ni/YSZ anode showed no significant degradation for $200 \mathrm{~h}$.

\section{Acknowledgement}

This research was supported by Basic Science Research Program through National Research Foundation of Korea (NRF) funded by the Ministry of Education (NRF-2018R1D1A1B07049226).

\section{References}

[1] S.C. Singhal, Solid State Ionics, 2002, 152, 405-410.

[2] A.B. Stambouli, E. Traversa, Renew. Sust. Energ. Rev., 2002, 6, 433-455.

[3] S. Park, J.M. Vohs, R.J. Gorte, Nature, 2000, 404, 265267.

[4] J.V. Herle, Y. Membrez, O. Bucheli, J. Power Sources, 2004, 127(1-2), 300-312.

[5] D.K. Niakolas, Appl. Catal.: A-Gen., 2014, 486, 123142.

[6] S. Zha, Z. Cheng, M. Liu, J. Electrochem. Soc., 2007, 154(2), B201-B206.

[7] R.J. Gorte, J.M. Vohs, J. Catal. 2003, 216(1-2), 477486.

[8] B.S. Prakash, S.S. Kumar, S.T. Aruna, Renew. Sust. Energ. Rev., 2014, 36, 149-179. 
[9] Z. Cheng, J.H. Wang, Y. Choi, L. Yang, M.C. Lin, M. Liu, Energ. Environ. Sci., 2011, 4(11), 4380-4409.

[10] J.J.A. Flores, M.L.Á. Rodríguez, G.A.Espinosa, J.V.A Vera, Int. J. Hydrogen. Energ, 2019. 44(24), 1252912542.

[11] S.P.S. Shaikh, A. Muchtar, M.R. Somalu, Renew. Sust. Energ. Rev., 2015, 51, 1-8.

[12] J.B. Goodenough, Y.H. Huang, J. Power Sources, 2007, 173(1), 1-10.

[13] J.B. Wang, J.C. Jang, T.J. Huang, J. Power Sources, 2003, 122(2), 122-131.

[14] M. Watanabe, H. Uchida, M. Shibata, N. Mochizuki, K. Amikura, J. Elecrochem. Soc., 1994, 141(2), 342-346.

[15] S.Sydyknazar, V.Cascos, M.T. Fernández-Diaz, J.A. Alonso, J. Materiomics, 2019, 5, 280-285.

[16] V.Cascos, L. Troncoso, J.A. Alonso, M.T. FernándesDiaz, Renew. Energ., 2017, 111, 476-483.

[17] S. Durán, N. Rangel, C. Silva, M.A. Macias, E. Capoen, C. Pirovano, A. Niemczyk, L. Suescun, P. Roussel, G.H. Gauthier, Solid State Ionics, 2019, 341, 115031.

[18] J. Zhou, N. Wang, J. Cui, J. Wang, J. Yang, Z. Zong, Z. Zhang, Q. Chen, X. Zheng, K. Wu, J. Alloy. Compd., 2019, 792, 1132-1140.

[19] M. Gou, R. Ren, W. Sun, C. Xu, X. Meng, Z. Wang, J. Qiao, K. Sun, Ceram. Int., 2019, 45(12), 15696-15704.

[20] J. Liu, J. Ding, L. Miao, Z. Gong, K. Li, W. Liu, J. Alloy. Compd., 2019, 786, 163-168.

[21] H.S. Kim, S.P. Yoon, J.W. Yun, S.A. Song, S.C. Jang,
S.W. Nam, Y.G. Shul, Int. J. Hydrogen Energ., 2012. 37(21), 16130-16139.

[22] J.M. Lee, J.W. Yun, Ceram. Int., 2016, 42(7), 86988705.

[23] E.K. Park, S. Lee, J.W. Yun, Appl. Surf. Sci., 2018, 429, 171-179.

[24] M.A. Gwan, J.W. Yun, J. Electroceram., 2018, 40(3), 171-179.

[25] H.Y. Zhu, P.F. Zhang, S. Dai, ACS. Catal, 2015, 5(11), 6370-6385.

[26] D.B. Meadowcroft, Nature, 1970, 226(5248), 847-848.

[27] J. Shim, K.J. Lopez, H.J. Sun, G. Park, J.C. An, S. Eom, S. Shimpalee, J.W. Weidner, J. Appl. Electrochem., 2015, 45(9), 1005-1012.

[28] D. Konwar, H.H. Yoon, J. Mater. Chem. A, 2016, 4(14), 5102-5106.

[29] Y. Zhang, N. Xu, H. Fan, M. Han, Energ. Procedia, 2019, 158, 2250-2255.

[30] D.W. Lee, J.H. Won, K.B. Shm, Mater. Lett., 2003, 57(22-23), 3346-3351.

[31] M. Popa, M. Kakihana, Solid State Ionics, 2002, 151(14), 251-257.

[32] Y. Sun, J. Li, Y. Zeng, B.S. Amirkhiz, M. Wang, Y. Behnamian, J. Luo, J. Mater. Chem. A, 2015, 3(20), 11048-11056.

[33] J.W. Yun, S.P. Yoon, H.S. Kim, J. Han, S.W. Nam, Int. J. Hydrogen Energ., 2012. 37(5), 4356-4366. 